\title{
Natural Chemoprotectants for Mitigating the Side Effects of Cancer
}

\section{Therapy}

Monu, Pushpa C. Tomar, Shilpa S. Chapadgaonkar*

Department of Biotechnology, Manav Rachna International Institute of Research Studies, Sector-43, Surajkund Road, Faridabad, Haryana, India

Key words: Chemoprevention, Toxicity, Antioxidants, Chemotherapy

\section{Introduction:}

Cancer is one of the leading causes of morbidity and mortality globally cancer is responsible for one in eight deaths worldwide which is more than AIDS, tuberculosis, and malaria while it has taken together. Moreover, the number of cancer deaths has been estimated to increase from 7.1 million in 2002 to 11.5 million in 2030 (Prakash et al., 2013). The most common strategies for the treatment of cancer usually include a combination of surgery, radiotherapy, and chemotherapy. Chemotherapeutic drugs usually target the rapidly dividing cells and hence affect the cancer cells that show uncontrolled growth. However, normal cells are also affected due to the cytotoxic effects of chemotherapy. This leads to serious side effects of the chemotherapeutic agents. Chemo-protectants are natural or synthetic chemical compounds that exhibit the ability to ameliorate or inhibit the toxic or adverse effects of chemotherapeutic agents and radiation therapy, without compromising the anticancer activity of the drugs or antitumor prospective of the chemotherapeutic drugs. Ideal chemo-protectants should not interfere with the therapeutic potential of the drugs and must not alter the normal serum enzyme levels or induce toxicity themselves. Recently a few chemical chemo-protectant drugs have been introduced that have been useful in ameliorating the side

\section{Abstract}

Globally cancer disease is one of the leading causes of morbidity and mortality. The most common strategies for the treatment of cancer usually include a combination of surgery, radiotherapy, and chemotherapy. Chemotherapeutic drugs usually target the rapidly dividing cells and hence affect the cancer cells that show uncontrolled growth. However, normal cells are also affected due to the cytotoxic effects of chemotherapy. This leads to serious side effects of the chemotherapeutic agents. Chemoprotectants are natural or synthetic chemical compounds that exhibit the ability to ameliorate or inhibit the toxic or adverse effects of chemotherapeutic agents and radiation therapy, without compromising the anticancer activity of the drugs or antitumor prospective of the chemotherapeutic drugs. Ideal chemo-protectants should not interfere with the therapeutic potential of the drugs and must not alter the normal serum enzyme levels or induce toxicity themselves. We focused on some recent chemo-protectants potentially are in use for treatment of cancer patients.

effects of chemotherapy (Table-1)

Table 1: Chemical Chemo-protectants \& respective mechanisms

Drug: Chemoprotectant

Mechanism

Cisplatin: Amifostine (Ethyol)

Free radicalsscavenger, Prevention of membrane damage, protection of DNA, protection from nephrotoxicity, decrease in neutropenia, reduction of xerostomia resulting from radiotherapy in head and neck cancer

Cisplatin, Doxorubicin: Aprepitant(Emend) Anti-emetic,anincrease in activity of ondansetron. Antiemetic action eases the strong emetic side effects of chemotherapy

Doxorubicin: Dexrazoxane Prevention of cardiomayopathycardiotoxicityin breast cancer

Filgrastim (Neupogen) ${ }^{\circledR}$ \& Sargramostim (Leukine) It can be used to prevent or treat neutropenia resulting from myeloablative chemotherapy

Mesna (sodium-2-mercapto-ethanesulfonate) : Cyclophosphamide \& ifosfamide Binds to acrolein which is a toxic metabolite generated by metabolism of these drugs

Doxorubicin inhibits topoisomerase 2 leading to inhibition of cancer cell proliferation. Cyclophosphamide is

*Corresponding Author: shilpas.fet@mriu.edu.in 
another chemotherapeutic drug that is known to cause bladder toxicity and cardiotoxicity and suppresses the immune system. Dexrazoxane is used to lower the undesired side effects of Doxorubicin (Pommier et al., 2010). Amifostine is the generic name of drug Ethyol which reduces the side effects of chemotherapy. It can be also used to cure dry mouth problems and neck cancer treatment undergoing patients. Glutathione has been reported as a potential chemo-protectant. Mesna alleviates the toxic effects of ifosfamide and cyclophosphamide which produce acrolein which is toxic to the bladder (Beauchamp et al., 1985). Many natural compounds have been discovered that have chemoprotective potential. These chemo-protectants have different activities including anticancer, antitumor, anti-angiogenic, and antioxidant compounds. Some of the chemo-protectants have been used as adjuvants in cancer chemotherapy(Piccolella \& Pacifico, 2015). Many natural products have been the most important and vital source in drug development and discovery from ages. The ancient knowledge of traditional medicines has been proven to behave several health benefits. Some of these natural chemo-protectants have been listed in the table-2.

\begin{tabular}{|c|c|c|c|}
\hline Source & $\begin{array}{l}\text { Active } \\
\text { compound }\end{array}$ & $\begin{array}{l}\text { Chemo-protective } \\
\text { Effect }\end{array}$ & $\begin{array}{l}\text { Reference } \\
\text { (Year) }\end{array}$ \\
\hline $\begin{array}{l}\text { Grapes, } \\
\text { berries }\end{array}$ & Resveratrol & $\begin{array}{l}\text { Neuroprotective, } \\
\text { cardioprotective \& } \\
\text { hepaticoprotective }\end{array}$ & $\begin{array}{l}\text { Scalbert et al. } \\
(2005)\end{array}$ \\
\hline Grapes & Cyanidin & $\begin{array}{l}\text { Inhibit cell } \\
\text { proliferation }\end{array}$ & $\begin{array}{l}\text { Singh et al. } \\
(2016)\end{array}$ \\
\hline Tomato & $\begin{array}{l}\text { Lycopene, (red } \\
\text { carrots, water- } \\
\text { melons, \& red } \\
\text { papayas) }\end{array}$ & $\begin{array}{l}\text { Chemo-preventive } \\
\text { in prostate cancer } \\
\text { effects. }\end{array}$ & $\begin{array}{l}\text { Agarwal et al. } \\
\text { (2001) }\end{array}$ \\
\hline $\begin{array}{l}\text { Tea, } \\
\text { Broccoli, } \\
\text { Grapes }\end{array}$ & Kaempferol & $\begin{array}{l}\text { Antiangiogenic,anti- } \\
\text { cancer \& radical } \\
\text { scavenging effects }\end{array}$ & $\begin{array}{l}\text { Boam (2015) } \\
\text { Luo et al. } \\
(2009)\end{array}$ \\
\hline Turmeric & Curcumin & $\begin{array}{l}\text { Induces apoptosis } \\
\text { in tumour cells }\end{array}$ & $\begin{array}{l}\text { Shehzad et al. } \\
(2010)\end{array}$ \\
\hline $\begin{array}{l}\text { Green } \\
\text { peppers }\end{array}$ & Luteolin & $\begin{array}{l}\text { Induces apoptosis \& } \\
\text { inhibit the cell } \\
\text { proliferation,metas- } \\
\text { tasis \& angiogenesis } \\
\text { in tumour cells }\end{array}$ & $\begin{array}{l}\text { Lin et al. } \\
(2008)\end{array}$ \\
\hline Soy beans & Genistein & $\begin{array}{l}\text { Increased tumour } \\
\text { latency period, } \\
\text { suppress tumour } \\
\text { growth }\end{array}$ & $\begin{array}{l}\text { Sarkar \& Li } \\
(2004)\end{array}$ \\
\hline $\begin{array}{l}\text { Ashw- } \\
\text { gandha }\end{array}$ & Withaferin & $\begin{array}{l}\text { Inhibit cell proli- } \\
\text { feration umblical } \\
\text { vein endothelial } \\
\text { cell (HUVEC) }\end{array}$ & $\begin{array}{l}\text { Palliyaguru et } \\
\text { al. (2016) } \\
\text { Lee \& Choi } \\
(2016)\end{array}$ \\
\hline $\begin{array}{l}\text { Bitter } \\
\text { melon }\end{array}$ & $\begin{array}{l}\text { Momocharin, } \\
\text { momordicin }\end{array}$ & $\begin{array}{l}\text { Inhibition of cancer } \\
\text { cell \& cancer stem } \\
\text { cell growth, induc- } \\
\text { tion of apoptosis }\end{array}$ & $\begin{array}{l}\text { Dandawate } \\
\text { et al. (2016) }\end{array}$ \\
\hline
\end{tabular}

\section{Anticancer compound obtained from plants Polyphenols:}

Reservatrol: it is present in many foods like peanuts, grapes, and red wines. Green tea has the polyphenolic compound gallactechines. Many studies show that consuming the food which has polyphenols reduces the risk of cancer and act as a natural antioxidant. (Scalbert et al., 2005). Polyphenols have been shown to interfere with proteins of cancer cells and retard their growth. Polyphenols induce acetylation, methylation or phosphorylation in the cancer cell. Many studies reveal that the TNF factor is suppressed by curcumin treatment. Resveratrol degrades the DNA in the presence of culI. (Gonzalez et al., 2011).

Brassinosteroids: these are compounds which occur naturally in plants. They participate in hormone signalling for growth and differentiation of cells root cells and stem cell elongation and other functions such as disease resistance and stress tolerance. Brassinosteroids are known to be capable of growth inhibition in cell lines ofT- cell leukaemia, multiple myeloma, cervical carcinoma, lung carcinoma and osteosarcoma. Brassinosteroids have an affinity towards Estrogen receptor (ER) and Epithelial growth factor receptor (EGFR-2) and it has the anticancer activity, due to blocking capacity of these receptors. Brassinosteroids are nontoxic and can be taken orally as part of the patient's dietary intake (Greenwell et al., 2015).

Cyanidin: this pigment can be extracted from red berries such as grapes, blackberry, cranberry etc. Inclusion of these berries in the diet lowers the risk of cancer which has been attributed to antioxidant and radical scavenging properties. They inhibit cancer cell proliferation by inhibiting NOS and $\mathrm{COX}_{2}$ genes in colon cancer. Moreover, Yarla et al., 2016 reported that cyanidin blocked Fyn kinase signalling. Moreover, ethanol-induced activation of $\mathrm{ErbB}_{2} / \mathrm{CSrc} / \mathrm{FAK}$ was inhibited by cyaniding-3-glucoside in breast cancer cells. Cyanidin-3-O-rutinoside, cyanidin-3-O-glucoside, and ethanol extract of raspberries selectively inhibited growth and induced apoptosis in tumorigenic rat oesophagus cell line. Prostaglandin $\mathrm{E}_{2}$ secretion and UVB induced $\mathrm{COX}_{2}$ expression are blocked by cyanidin in the epidermal skin cell line. It is due to the suppression of NF$\kappa \beta$ and $\mathrm{AP}-1$ that is regulated by MAPK (Zhou et al., 2009).

Lycopene: it is a red colour phytochemical pigment present in red carrots, red papayas, tomatoes and red watermelon it is concluded that lycopene showing chemopreventive effects and also having the antioxidant property (Konijeti et al., 2010). Lycopene is known to be used in prostate cancer. It activates cancer-preventive enzymes and acts on phase 2 detoxification. It also the cause of inhibition of cancer cell proliferation and suppress the insulin -growth factor. Lycopene has been shown to be effective in cancers like Breast cancer, endometrial cancer, colon cancer, prostate 
GENERAL ARTICLE

cancer (Agarwal et al., 2001).

Kaempferol: it is found in various fruits and vegetables like tea broccoli, grape etc. kaempferol possesses antiangiogenic, anticancer, and radical scavenging effects (Tu et al., 2016). Kaempferol shows cytostatic activity in $\mathrm{PC}_{3}, \mathrm{HeLa}$ and $\mathrm{K}_{562}$ human cancer cell lines. Kaempferol acts as an aryl hydrocarbon receptor $(\mathrm{AhR})$ antagonist resulting in $\mathrm{ABCG}_{2}$ upregulation (Nagula \& Wairkar, 2019). It was reported that it induces apoptosis in ovarian cancer cells by $\mathrm{p} 5$ also found that kaempferol induces p53 mediated apoptosis, (Gopalakrishnan et al., 2008).

\section{References:}

Agarwal, A., Shen, H., Agarwal, S., \& Rao, A.V. (2001): Lycopene content of tomato products: its stability, bioavailability and in vivo antioxidant properties. J. Med. Food, 4(1):9-15.

Beauchamp, R.O., Andjelkovich, D.A., Kligerman, A.D., Morgan, K.T., Heck, H.D.A. \& Feron,V.J. (1985): A critical review of the literature on acrolein toxicity. Crit. Rev. Toxicol., 14(4):309380.

Boam, T. (2015): Anti-androgenic effects of flavonols in prostate cancer. Ecancer Med. Sci., 9:585.

Dandawate, P.R., Subramaniam, D., Padhye, S.B., \& Anant, S. (2016): Bitter melon: a panacea for inflammation and cancer. Chin. J. Nat. Med., 14(2):81-100.

González, R., Ballester, I., López-Posadas, R., Suárez, M.D., Zarzuelo, A., Martinez-Augustin, O. \& Medina, F.S.D. (2011): Effects of flavonoids and other polyphenols on inflammation. Crit. Rev. FoodSci. Nutr., 51(4):331-362.

Gopalakrishnan, A. \& Kong, A.N.T. (2008): Anticarcinogenesis by dietary phytochemicals: cytoprotection by $\mathrm{Nrf}_{2}$ in normal cells and cytotoxicity by modulation of transcription factors NF- $\kappa \beta$ and AP-1 in abnormal cancer cells. Food Chem. Toxicol., 46(4):1257-1270.

Greenwell, M. \& Rahman, P.K.(2015): Medicinal plants: their use in anticancer treatment. Int. J. Pharm. Sci. Res., 6(10):4103-4112.

Konijeti, R., Henning, S., Moro, A., Sheikh, A., Elashoff, D., Shapiro, A., Ku, M., Said, J.W., Heber, D., Cohen, P.,\& Aronson, W. J. (2010): Chemoprevention of prostate cancer with lycopene in the TRAMP model. Prostate, 70(14):15471554 .

Lee, I. C., \& Choi, B. Y. (2016): Withaferin-A--A Natural Anticancer Agent with Pleitropic Mechanisms of Action. Int. J. Mol. Sci., 17(3):290.
Ambient Science, 2019: Vol. 06(Sp1); Online DOI:10.21276/ambi.2019.06.sp1.ga01

Lin, Y., Shi, R., Wang, X., \& Shen, H. M. (2008): Luteolin, a flavonoid with potential for cancer prevention and therapy. Curr. Cancer Drug Targets, 8(7):634-646.

Nagula, R.L. \& Wairkar, S. (2019): Recent advances in topical delivery of flavonoids: A review.J. Controlled Release, 296:190-201.

Palliyaguru, D. L., Singh, S. V., \& Kensler, T. W. (2016): Withania somnifera: From prevention to treatment of cancer. Mol. Nutr. Food Res., 6o(6):1342-1353.

Piccolella, S., \& Pacifico, S. (2015): Chapter Five- Plant-derived polyphenols: a chemopreventive and chemoprotectant worth-exploring resource in toxicology, pp. 161-214. In: Advances in molecular toxicology (Vol. 9). Pub. by: Elsevier.

Pommier, Y., Leo, E., Zhang, H. \& Marchand, C. (2010): DNA topoisomerases and their poisoning by anticancer and antibacterial drugs. Chem. Biol., 17(5), 421-433.

Prakash, O.M., Kumar, A. \& Kumar, P. (2013): Anticancer potential of plants and natural products. Am. J. Pharmacol. Sci., 1(6):104-115.

Sarkar, F.H., \& Li, Y. (2004): The role of isoflavones in cancer chemoprevention. Front. Biosci., 9(1):2714-2724.

Scalbert, A., Johnson, I.T. \& Saltmarsh, M. (2005): Polyphenols: antioxidants and beyond. Am.J. Clin.Nutr., 81(1):215S-217S.

Shehzad, A., Wahid, F. \& Lee, Y. S. (2010): Curcumin in cancer chemoprevention: molecular targets, pharmacokinetics, bioavailability, and clinical trials. Arch. Pharm., 343(9):489499.

Singh, C. K., Siddiqui, I. A., El-Abd, S., Mukhtar, H., \& Ahmad, N. (2016): Combination chemoprevention with grape antioxidants. Mol. Nutr. Food Res., 6o(6):1406-1415.

Tu, L.Y., Bai, H.H., Cai, J. Y. \& Deng, S.P. (2016): The mechanism of kaempferol induced apoptosis and inhibited proliferation in human cervical cancer SiHa cell: From macro to nano. Scanning, 38(6):644-653.

Yarla, N.S., Bishayee, A., Sethi, G., Reddanna, P., Kalle, A.M., Dhananjaya, B. L. \& Duddukuri, G.R. (2016): Targeting arachidonic acid pathway by natural products for cancer prevention and therapy. Seminars Cancer Biol., 40-41:48-81).

Zhou, Q.M., Wang, S., Zhang, H., Lu, Y.Y., Wang, X. F., Motoo, Y., \& $\mathrm{Su}$, S.B. (2009): The combination of baicalin and baicalein enhances apoptosis via the ERK/p38 MAPK pathway in human breast cancer cells. Acta Pharmacol. Sin., 30(12):16481658. 